\title{
The Impact of Using Task-Based Activities on Iranian EFL Learners' Speaking Skill
}

\author{
'Atefeh Shamsy, ${ }^{2}$ Rasoul Mombeini \\ Email: Atefehshams19@gmail.com \\ ${ }^{1}$ English Department, Abadan Branch, Islamic Azad University, Abadan, Iran \\ ${ }^{2}$ English Department, Ahvaz Branch, Islamic Azad University, Ahvaz, Iran \\ Email: Rasoul.tighen@gmail.com
}

\begin{abstract}
This study explored the impacts of task-based activities on Iranian intermediate EFL learners' speaking skill. To do the current study, the Oxford Quick Placement Test (OQPT) was given to 75 students and 50 intermediate participants whose scores were between 40 and 47 were selected. Then, the participants were randomly divided into two groups; one experimental group and one control group. Then they were given three topics to talk about in two minutes as a speaking pre-test. Afterwards, the experimental group received the treatment through task-based activities while the control group received a traditional instruction. The whole instruction lasted eight sessions. In the first two sessions, the OQPT and the pre-test were administered, respectively; in five sessions, the participants received the treatment, and in the eighth session, the post-test of speaking was given to the participants of both groups to measure the effects of the treatment on their speaking improvement. The collected data were analyzed through independent and paired samples t-tests and the results indicated that the experimental group outperformed the control group on the posttest. In other words, there was a significant difference between the speaking post-test of the two groups. The implications, the conclusions, the limitations, and the suggestions of the research were explained.
\end{abstract}

Keywords: Task-based activities, Iranian EFL learners, Speaking skill

\section{Introduction}

Speaking, among the four major skills, seems mostly favored as every English language learner aspires to be effective in communication with others in oral mode. The importance of teaching speaking skill is that the language is acquired through speaking and listening before one learns reading and writing
(Brown \& Yule, 1983). Speaking is perceived as measurement of people's language mastery. Speaking is also the most important language skill that needs to be controlled, and they assess learning achievement based on mastery of speaking skills (Burnkart, 1998; Namaziandost et al., 2021b). People who know the language are referred to as "speaker" of that language, as if speaking included all other kinds of knowing; 
and many, if not most foreign language learners, are primarily interested in learning to speak (Nazara, 2011; Namaziandost et al., 2021a). This skill is important for communication among people in the society in order to convey information and ideas, and maintain social relationship.

Brown and Yule (1983) state many language learners regard speaking as the criteria for knowing a language and progress is assessed in terms of success in spoken communication. Therefore, it is important if teachers teach students how to speak strategically for effective communication. One approach to teach speaking is Task-based language teaching (TBLT) approach which provides many advantages for teachers who make the students enthusiastic because TBLT approach offers the language experience in the classroom. TBLT focuses on learners using language naturally in pairs or group work and allowing them to share ideas (Nunan, 2004; Namaziandost, Shafiee, $\&$ Ziafar, 2020). It encourages them to be actively involved in the learning process.

TBLT is one of the most effective and meaningful language teaching approaches in recent years, which emphasizes on learning by doing and performing with language (Larsen-Freeman, 2000). Communicative language teaching advocates taskbased language instruction. Teachers can provide their students with task-based activities, which will make any syllabus more effective by making it student-centered, relevant and motivating. TBLT offers an effective means to motivate students to learn and gives them confidence to succeed (Larsen-Freeman, 2000; Namaziandost, Sawalmeh, \& Izadpanah Soltanabadi, 2020). A task-based approach for teaching speaking tries to encounter learners with a natural authentic context. One of the best practices to provide interaction opportunities for learners is their group work to complete a task, as they must interact with each other, understand each other, express their own ideas, check their own comprehension, seek clarification, and assimilate the language that they listen and may be beyond their present ability (Larsen-Freeman, 2000).

\subsection{Statement of the Problem}

Some of Iranian EFL learners have lots of problems when they speak with their interlocutors in the target language. Many Iranian EFL learners are grammatically proficient and also, they know abundant English vocabulary items but they fail to communicate fluently. In addition, after studying English for some years, numerous EFL learners are not satisfied with their speaking proficiency level and become demotivated gradually.

In Iranian EFL context, few studies have been carried out to examine the effects of task-based speaking activities on speaking skill in general and on speaking fluency in specific (Hashemifardnia, Rasooyar, \& Sepehri, 2019; Namaziandost \& Çakmak, 2020). Therefore, this study endeavored to see whether Iranian EFL learners could benefit from using task-based speaking activities. The current study was among the few that examined the effects of task-based activities on speaking skill of EFL learners. 


\subsection{Objectives and Significance of the Study}

The aim of the current study was to help Iranian EFL learners to improve their speaking skill through using task-based activities. Therefore, one main objective was followed in this study; this study investigated the effects of using task-based activities Iranian EFL learners' speaking skill.

This study is significant since it provides some implications both for English teachers and learners to improve their speaking skill. In addition, this study can be significant since its results can open a new window of opportunity for novice researchers who are willing to carry out new empirical studies in the domain of task-based instruction. This research can be significant since it can enrich the growing body of research in the domain of task-based activities and speaking skill.

\subsection{Research Question and Null Hypothesis}

This study aimed to answer the following research question:

RQ1. Does using task-based activities have any significant impact on Iranian intermediate EFL learners' speaking skill?

Based on the above-mentioned question, the following null hypothesis was suggested:

HO1. Using task-based activities does not have any significant impact on Iranian intermediate EFL learners' speaking skill.

\section{Review of the Literature 2.1 Theoretical Background}

Because task-based work involves holistic language processing, it can generate a rich range of learning processes (Long, 2009). One is the process of relating the language user's intention to meaning, and meaning to linguistic form. That is, in order to achieve task goals, during task communication, students identify relevant meanings, and try to map them to relevant words and phrases; indeed, much learning occurs by association, simply through exposure to language input that has not been disarticulated from context, content, and purpose (i.e., the holistic task). This leads learners to explore relationships between words and meanings, interrelating meanings and appropriate language, and learning how to do things with words (Long, 2009). This is the core of a TBLT approach: in particular, contextually relevant meanings are the reference point for developing implicit and explicit understanding of new language. This process often requires engaged interlocutors signaling whether they have understood or not. Successful communication is proof that learners have learned how to use parts of the language; unsuccessful communication is an opportunity for them to identify gaps in their knowledge, so they can find ways of filling them. Communication as a learning process thus requires a willingness to negotiate meaning, both referential (denoting concepts) and pragmatic (impacting other people's behaviors and attitudes) (Long, 2009; Shakibaei, Shahamat, \& Namaziandost, 2019).

Importantly, such negotiation can generate feedback on language gaps at the precise moment 
and context where learners need to learn. Researchers (e.g., Mackey, 2008) have found that negotiation for meaning, and other interactional moves such as scaffolding, recasting, and error corrections, can lead to effective learning, and that improved memory for vocabulary, grammar, and even pragmatics can be positively related to successful interaction between learners. In a similar vein, those working from a more socially grounded orientation (e.g., Mackey $\&$ Polio, 2009) have noted how by working jointly on tasks, learners can contribute mutually to each other's learning. It follows that the teacher too can play an important role in negotiation for meaning and broader interaction processes.

Task work can also help develop learners' fluency, complexity, accuracy, and appropriacy of language use. Research (Robinson, 2011; Skehan, 2014) showed that learners' attention can be drawn differentially to fluency, complexity, or accuracy in their performance with language by varying the kinds of task. Certain kinds of relatively simple tasks may tend to prioritize accuracy and fluency in performance, while more complex tasks (e.g., containing unstructured content or multiple elements to deal with) may lead to more grammatically complex, less fluent, and less accurate language, thereby helping to push interlanguage development (Robinson, 2011). Task conditions are also influential: pre-task planning time can lead to greater complexity and fluency, but less accuracy, whereas lack of time pressure results in greater accuracy.

The two factors which could determine the success of English language learners according to BBC British council are speaking accuracy and fluency. In second and foreign language teaching, speaking accuracy refers to the ability to produce grammatically correct sentences (Richards \& Schmidt, 2002). However, Harmer (2000) pointed that accuracy involves the correct use of vocabulary, grammar and pronunciation, which are considered by Thornbury (2000) as three criteria that most teachers have reliance on concerning the assessment of learner's command of the linguistic systems. Therefore, to be accurate in oral production, to be understood and to gain interest of their interlocutors; learners should pay attention to correctness and completeness of the language form; they should be knowledgeable and master the use of:

1. Vocabulary: which mean that learners should study words and know their meanings, their use, also they should be able to distinguish between words classes which are lexical one as nouns, verbs, adjectives, adverbs, or function one as determiners, particles, prepositions...etc. Mastering vocabulary helps learners to be able to select and use the appropriate words, utterances and expressions with the context when speaking.

2. Grammatical structures: Rules of words order, tenses...etc. This means that learners should know how elements of a sentence are put and work together such as morphemes, phonemes, words, phrases, clauses...etc.

3. Correct pronunciation: "production of sounds, stress patters, rhythmic structures and intonation of the language" (Florez, 1999, p. 2). 
According to Thornbery (2000), fluency is the "capability to produce language in real time without undue pausing or hesitation" (p. 3). In other words, speaking fluently is the faculty of using the language spontaneously and confidently while communicating one's thought, ideas or opinions in several contexts. It implies talking without making a lot of stops to think too much about what one's is saying and without worrying too much about errors (accuracy) until it becomes unnatural speech.

As pointed by Richards and Schmidt (2002) fluency is "the features which give speech the qualities of being natural and normal, including native-like use of pausing, rhythm, intonation, stress, rate of speaking, and use of interjections and interruptions (p. 204)". Therefore, teachers should rehearse learners to speak in a coherent manner by paying more attention to the meaning and context then to the form in order to achieve oral fluency. This latter "describes a level of proficiency in communication", which includes:

a. The ability to produce $[\ldots]$ spoken language with ease

b. The ability to speak with a good but not necessarily perfect command of intonation, vocabulary, and grammar

c. The ability to communicate ideas effectively

d. The ability to produce continuous speech without causing comprehension difficulties or a breakdown of communication" (Richards \& Schmidt, 2002, p. 204).

Skehan and Foster (1999) defined fluency as "the capacity to use language in real time, to emphasize meanings, possibly drawing on more lexicalized systems" (p. 96). Contrarily to accuracy and complexity, it is often associated with phonological phenomena. Researchers have investigated three dimensions of fluency: "speed fluency (rate and density of linguistic units produced), breakdown fluency (number, length and location of pauses), and repair fluency (false starts, misformulations, self-corrections and repetitions)" (Housen, Kuiken, \&Vedder, 2012, p. 5).

\subsection{Experimental Background}

Regarding the effectiveness of TBLT and taskbased activities, some experimental studies were conducted. Gunawan (2016) investigated the effect of using TBLT approach in developing students' speaking skill and to explore students' attitude toward the use of TBLT approach in teaching English speaking. Involving two classes as the experimental class and the control class which consisted of 60 students, selected by using Cluster Random Sampling technique. The research applied quasi-experimental method. The population of the research was the eighth grade students of SMP Negeri Watampone in academic year 2015/2016. The data were collected through speaking test and questionnaires then analyzed by paired-samples t-test. The result of the research showed that (1) the use of TBLT approach in teaching speaking significantly improved the students' speaking skill. The mean score of students' posttests in the experimental group was 70.00 and the mean score of students' posttests in the control group was 58.66. It signifies that the improvement of the experimental group was higher than that of the control group. (2) The students' attitude toward the use of TBLT was strongly positive. 
Noshad and Zamanian (2017) explored the effect of applying task-based activities on students' listening comprehension improvement. It also aimed at providing evidence to show how shifting from a traditional language teaching approach into the TBLT approach can positively affect the process of learning listening skill. To do this, 80 participants were selected from three English language institutes in Shiraz. Participants of the study were chosen by assigning a placement test and they were divided into two groups. In the experimental group, the participants were taught listening skills based on the tenets of task-based teaching while the participants in the control group were taught listening skills traditionally. This process continued for 20 sessions. A pre-test and post-test were administered. One-way ANOVA, correlation and t-test analyses were used to determine whether differences between the sample means were statistically significant or not. It was found that the students of the experimental group, who experienced task-based principles of teaching listening, performed remarkably better than those of the control group on the final listening post-test. And it was concluded that there was a statistically significant difference between the effects of taskedbased activities and traditional activities on Iranian beginner EFL learner's listening comprehension.

Namazian Dost (2017) investigated the effect of the effect of task-based language teaching on motivation and grammatical achievement of EFL junior high school students of Ahvaz. To fulfill the objectives of the study a Homogeneity test (Oxford Quick Placement Test) was administered among 100 students at the junior high school and finally 80 participants were selected. Then, they were divided into two subgroups, namely control and experimental groups. Before starting the treatment, a validated teacher-made grammar test in terms of the materials supposed to be covered in both groups was administered to them as the pre-test. Moreover, a motivation questionnaire were given to both groups at the beginning and at the end of study. Then the experimental group received the treatment, which was teaching and learning grammar through using task-based language teaching and the control group received traditional teaching which is teaching grammar through instruction on examples and drills proposed by the teacher. After 12 sessions of treatment, the two groups were administered the same teacher-made grammar test as posttest. Data were analyzed by Paired and Independent Samples t-test. The findings showed that the experimental group significantly performed better than the control group. Generally, the experimental groups outperformed the control groups. Furthermore, the results of motivation questionnaire show that there was a significant difference between the experimental and control groups' motivation in the post-test of questionnaire which implies that the experimental group's motivation increased significantly. The results suggested that task-based language teaching can be used in English classes to develop grammar ability among Iranian EFL learners.

In another study, Hashemifardnia et. al., (2019) examined the effects of task-based activities on Iranian EFL learners' speaking fluency. To this end, 50 Iranian participants were selected from among 67 students based on the results of Oxford Quick Placement Test (OQPT). The selected intermediate participants were then randomly divided into two 
equal groups; experimental and control. Then, a pre-test of speaking was administered to measure the participants' English speaking. Afterwards, the treatment was started; in the first session of the treatment, the task of "buying" was given to the participants to be performed in a near authentic context. The researchers provided the context in which the participants could buy things such as pens, notebooks, and pencil cases. In the second, the third, and the fourth sessions of the treatment, the task of "ordering food", "ordering a bus ticket", and "visiting a doctor" were given to the participants, respectively. The control group on the other hand received traditional instruction, in fact, they did not receive task-based instruction. At the end of the treatment, a post-test of speaking was given to both groups to assess the impacts of task-based instruction on their speaking fluency. The obtained results showed that there was a significant difference between the posttests of the experimental and the control groups. The findings revealed that the experimental group significantly outperformed the control group $(p<$ $.05)$ on the post-test.

The reviewed literature above shows the importance of TBLT and task-based activities in language learning and teaching. Most of the experimental studies mentioned above proved the effectiveness of TBLT and task-based activities in a second or a foreign language. The above related studies suggest that further research is needed to investigate the effect of the task-based activities on Iranian EFL learners' English language improvement. Though some experimental studies were conducted to examine the effects of task-based activities on language learning, little attention has been paid to task-based activities. In fact, the effects of task-based activities have not been inspected on speaking skill of EFL learners. Therefore, the present study examined the impacts of task-based activities on developing Iranian intermediate EFL learners' speaking skill.

\section{Method}

\subsection{Participants}

Fifty participants were chosen among 75 students based on the results of Oxford Quick Placement Test (OQPT). They were selected from English Language Institute of Poyesh, Ahvaz City, Iran. The English proficiency level of the participants was intermediate and their age range was between 14 and 17 years old. All the participants were female and their first language was Persian. The target participants were randomly divided into two groups- one experimental group and one control group.

\subsection{Instruments}

The first instrument which was used in the current study was the OQPT. This test was used to homogenize the participants. It assisted the researchers to have a greater understanding of what level (i.e., elementary, pre-intermediate, intermediate) their participants were at. This test had 60 multiple-choice items and based on it the learners whose scores were 0 to 10 were considered as beginners; the learners whose scores were 10 to 29 were elementary; those learners whose scores were 30 to 39 were pre- intermediate; the students whose scores were 40 to 47 were intermediate; the learners whose scores were 48 to 54 were considered as the advanced learners and those whose scores were 55 to 
60 were very advanced learners. Based on the results of this test, 50 intermediate students were regarded as the target participants of the current research.

The second and the most important instrument for gathering information was a researcher-made speaking pre-test. The pre-test included two topics from the participants" textbook (i.e., Family and Friends 4). The participants were asked to talk about the topics about 2 to 3 minutes and their speech was recorded for the second rater. The reliability of the pre-test was calculated through inter-rater reliability by means of Pearson correlation analysis $(\mathrm{r}=81)$.

The third instrument of this study was a posttest of speaking: The post-test was similar to the pretest in form but different in topics. The topics of this test were selected from the mentioned textbook. The participants were required to talk about the topics about 2 to 3 minutes and their speech was recorded for the second rater. The reliability of the post-test was computed through inter-rater reliability by means of Pearson correlation analysis $(r=83)$. The pre and post-tests were validated by four English experienced teachers.

The fourth instrument was the speaking checklist (Hughes, 2003). It was used to aid the raters score the participants' speech. The raters scored the participants' speech based on the mentioned speaking checklist.

\subsection{Data Collection Procedure}

To do this study, first, the OQPT was administered in order to manifest the participants' homogeneity in terms of English language proficiency. Fifty participants out of 75 were selected for the target population of the current study. The participants were then randomly divided into two equal groups- one experimental and one control. Afterwards, the groups were pretested by a speaking pre-test. Then, the participants of the experimental group received the treatment based on the task-based activities.

In each session, the experimental group was given a topic to be discussed in the group. For example, in the first session of the treatment, the task of "buying a ticket" was given to the students to do it in a near authentic context. The researchers provided the context in which the students could buy a ticket. Five topics were worked in the similar way. The topics were "buying a ticket, buying clothes, making food, ordering food in a restaurant, and going to a picnic." The control group on the other hand was taught through a traditional instruction. They were required to do the activities individually without cooperation with their classmates. At the end of the treatment, a post-test of speaking was administered to both groups in order to determine the effects of task-based instruction on their speaking skill.

The whole instruction toke eight sessions. In the first two sessions, the OQPT and the pre-test were administered, respectively; in five sessions, the participants received the treatment, and in the eighth session, the post-test of speaking was given to the participants of both groups to determine the impacts of the treatment on their speaking skill. 


\subsection{Data Analysis Procedure}

The gathered data were analyzed through using SPSS software, version 22. Firstly, KolmogorovSmirnov (K-S) test was used to check the quality of data normality. Secondly, descriptive statistics was calculated. Thirdly, paired samples t-test and independent samples $t$-test were run to measure the effects of the treatment on the students' speaking skill.

\section{Results of the Study}

In this part, both descriptive statistics and inferential statistics were utilized to analyze the gathered data. K-S test was used to check the normality of the pre and post-tests scores. Descriptive statistics were calculated and compared. Values such as means and standard deviations were computed to summarize the participants' scores on the tests. Details are presented below.

Table 1:

One-Sample Kolmogorov-Smirnov Test (Groups' Pre and Post-tests)

\begin{tabular}{|c|c|c|c|c|c|}
\hline \multirow[b]{2}{*}{$\mathrm{N}$} & & \multirow{2}{*}{$\begin{array}{r}\text { Control pretest } \\
25\end{array}$} & \multirow{2}{*}{$\begin{array}{l}\begin{array}{c}\text { Experimental } \\
\text { pretest }\end{array} \\
\\
25\end{array}$} & \multirow{2}{*}{$\begin{array}{r}\text { Control posttest } \\
25\end{array}$} & \multirow{2}{*}{$\begin{array}{l}\begin{array}{l}\text { Experimental post- } \\
\text { test }\end{array} \\
25\end{array}$} \\
\hline & & & & & \\
\hline \multirow{2}{*}{$\begin{array}{l}\text { Normal } \\
\text { Parameters }{ }^{\mathrm{a}, \mathrm{b}}\end{array}$} & Mean & 13. 8000 & 13.5000 & 13.9200 & 18.1500 \\
\hline & Std. Deviation & 2.92859 & 2.39931 & 2.15870 & 1.78699 \\
\hline \multirow{3}{*}{$\begin{array}{l}\text { Most Extreme Dif- } \\
\text { ferences }\end{array}$} & Absolute & .231 & .192 & .225 & .294 \\
\hline & Positive & .231 & .192 & .225 & .215 \\
\hline & Negative & -.146 & -.165 & -.192 & -.294 \\
\hline \multicolumn{2}{|c|}{ Kolmogorov-Smirnov Z } & 1.154 & .961 & 1.125 & 1.468 \\
\hline \multicolumn{2}{|c|}{ Asymp. Sig. (2-tailed) } & .319 & .293 & 202 & .138 \\
\hline
\end{tabular}

a. Test distribution is Normal.

b. Calculated from data.

Table 1 shows that the statistics of scores is normal as the results obtained from using SPSS 22. In this case, the parametric statistics like independent samples t-test and paired samples t-test can be used to get the final results. 
Table 2:

Descriptive Statistics (Pre-test of Both Groups)

\begin{tabular}{|c|c|c|c|c|c|}
\hline & Groups & N & Mean & Std. Deviation & Std. Error Mean \\
\hline \multirow[t]{2}{*}{ Pretest } & Control & 25 & 13.8000 & 2.91859 & .58472 \\
\hline & Experimental & 25 & 13.5000 & 2.39831 & .47086 \\
\hline
\end{tabular}

In table 2, the descriptive statistics of both groups is presented. The control group's mean score is 13.08 and the experimental group's mean score is 13.56. This means that the both groups were at almost the same level before receiving the treatment.

Table 3:

Independent Samples t-test (Pre-test of Both Groups)

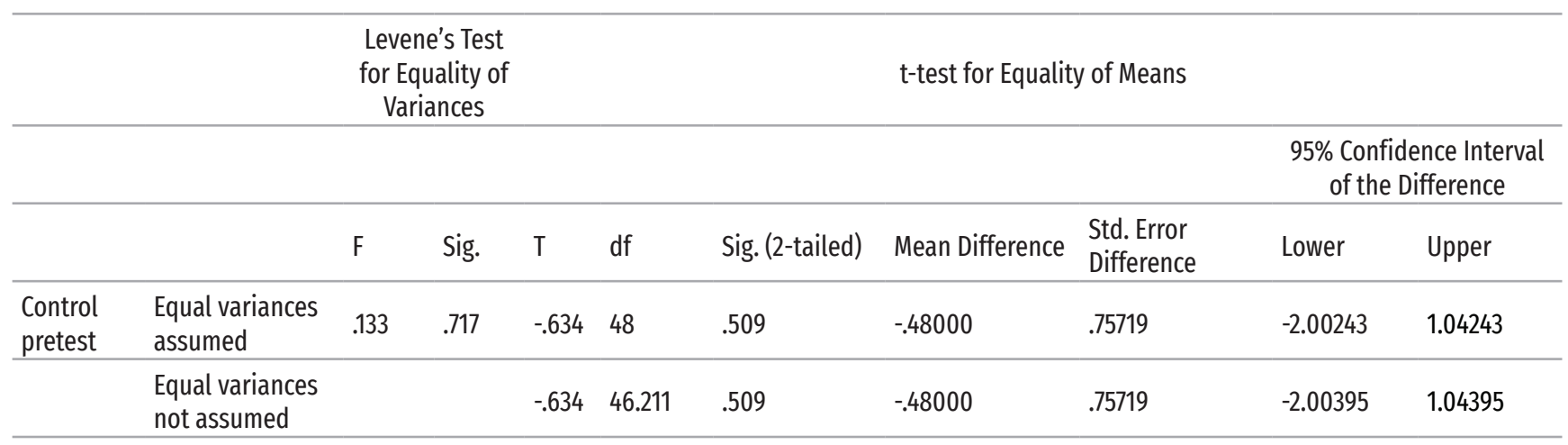

In Table 3, an independent samples t-test was used to show the scores of both groups on the pretest. Since the Sig (.509) is greater than 0.05 , the difference between the groups is not significant at $(\mathrm{p}<0.05)$. In fact, both groups had equal performances on the pre-test.

Table 4:

Descriptive Statistics (Post-test of Both Groups

\begin{tabular}{llccrr}
\hline & Groups & N & Mean & Std. Deviation & Std. Error Mean \\
\hline Posttest & Control & 25 & 13.9200 & 2.15870 & .43174 \\
\hline & Experimental & 25 & 18.1500 & 1.78699 & .35740 \\
\hline
\end{tabular}

Table 4 reveals the descriptive statistics of both groups on the post-test. The control group's mean score is 13.92 and the experimental group's mean score is 18.15 . It seems that the experimental group outperformed the control group on the post-test. 
Table 5:

Independent Samples t-test (the Post-test of Both Groups)

\begin{tabular}{|c|c|c|c|c|c|c|c|c|c|c|}
\hline & & \multicolumn{4}{|c|}{$\begin{array}{l}\text { Levene's Test } \\
\text { for Equality of } \\
\text { Variances }\end{array}$} & \multicolumn{3}{|c|}{ t-test for Equality of Means } & \multirow{2}{*}{\multicolumn{2}{|c|}{$\begin{array}{c}95 \% \text { Confidence Interva } \\
\text { of the Difference }\end{array}$}} \\
\hline & & & & & & & & & & \\
\hline & & $\mathrm{F}$ & Sig. & $\mathrm{T}$ & Df & Sig. (2-tailed) & $\begin{array}{l}\text { Mean } \\
\text { Difference }\end{array}$ & $\begin{array}{l}\text { Std. Error } \\
\text { Difference }\end{array}$ & Lower & Upper \\
\hline \multirow[t]{2}{*}{ Posttest } & Equal variances assumed & .512 & .478 & -7.494 & 48 & .000 & -4.20000 & .56048 & -5.32691 & -3.07309 \\
\hline & $\begin{array}{l}\text { Equal variances not } \\
\text { assumed }\end{array}$ & & & -7.494 & 46.382 & .000 & -4.20000 & .56048 & -5.32793 & -3.07207 \\
\hline
\end{tabular}

Table 5 indicates that the difference between the both groups is significant at $(\mathrm{p}<0.05)$ since Sig $(.000)$ is less than 0.05 . In fact, the experimental group had better performance than the control group on the post-test.

Table 6:

Paired Samples Statistics (Pre and Post-tests of Both Group)

\begin{tabular}{|c|c|c|c|c|c|}
\hline & & Mean & $\mathrm{N}$ & Std. Deviation & Std. Error Mean \\
\hline \multirow{2}{*}{ Pair 1} & Precon & 13.8000 & 25 & 2.46644 & .49329 \\
\hline & Postcon & 13.9200 & 25 & 2.95804 & .59161 \\
\hline \multirow{2}{*}{ Pair 2} & Preexp & 13.5000 & 25 & 2.66020 & .53204 \\
\hline & postexp & 18.1500 & 25 & 1.78699 & .35740 \\
\hline
\end{tabular}

Based on the descriptive statistics in the above the mean scores of the experimental group on the table, the mean scores of the control group on the pre pre and post-tests are 13.56 and 18.15 , respectively. and post-tests are 13.08 and 13.92, respectively, and 
Table 7:

Paired Samples Test (Pre and Post-tests of Both Group)

\begin{tabular}{|c|c|c|c|c|c|c|c|c|c|}
\hline & & \multicolumn{5}{|c|}{ Paired Differences } & \multirow{3}{*}{$\mathrm{t}$} & \multirow{3}{*}{ df } & \multirow{3}{*}{$\begin{array}{c}\text { Sig. } \\
\text { (2-tailed) }\end{array}$} \\
\hline & & \multicolumn{5}{|c|}{$\begin{array}{l}95 \% \text { Confidence Interval of } \\
\text { the Difference }\end{array}$} & & & \\
\hline & & Mean & Std. Deviation & $\begin{array}{l}\text { Std. Error } \\
\text { Mean }\end{array}$ & Lower & Upper & & & \\
\hline $\begin{array}{l}\text { Pair } \\
1\end{array}$ & Control pretest - control posttest & -.84 & 2.47 & .49 & -1.86 & .18 & -1.695 & 24 & .132 \\
\hline $\begin{array}{l}\text { Pair } \\
2\end{array}$ & $\begin{array}{l}\text { Experimental pretest - experimental } \\
\text { posttest }\end{array}$ & -4.56 & 1.38 & .27 & -5.13 & -3.98 & -1.440 & 24 & .000 \\
\hline
\end{tabular}

In the above table, a paired samples t-test is used to compare the pre and post-tests of the control group. The difference between the post-test and the pre-test of this group is not significant since Sig (.132) is greater than 0.05 , while the difference between the post-test and the pre-test of the experimental group is significant since $\operatorname{Sig}(.000)$ is less than 0.05 .

\section{Discussion of the Results}

In order to answer the research question, the researchers compared the scores of two groups on the pre and post-tests. After analyzing the data, the results showed that there was not a significant difference between the performances of both groups on the pre-test, but in contrast there was a significant difference between the performances of the two groups on the post-tests. Since the experimental group outperformed the control group, teaching through using task-based activities is supposed to improve the speaking skill of Iranian EFL learners.

Task-based activities enabled EFL learners to improve their speaking skill successfully. Doing tasks can involve the students in learning process.
Also, task-based learning can provide students with opportunities to use language creatively. The findings gained highlight the potential benefits of task-based activities in language classes which can positively affect language improvement among EFL learners.

The results of the present study are in line with Gunawan (2016) who investigated the effect of using task-based language teaching approach in developing students' speaking skill and to explore students' attitude toward the use of task- based language teaching approach in teaching English speaking. The result of the research showed that the use of task-based language teaching approach in teaching speaking significantly improved the students' speaking skill.

The findings of the present study are supported by Namazian Dost (2017) who examined the effect of task-based language teaching on motivation and grammatical achievement of EFL junior high school students of Ahvaz. The findings showed that the experimental group significantly performed better than the control group. Generally, the experimental group outperformed the control group. The results 
suggested that task-based language teaching can be used in English classes to develop grammar ability among Iranian EFL learners.

The findings of this study are also advocated by Hashemifardnia et. al., (2019) who examined the effects of task-based activities on Iranian EFL learners' speaking fluency. The obtained results indicated that there was a significant difference between the posttests of the experimental and the control groups. The findings showed that the experimental group significantly outflanked the control group $(p<.05)$ on the post-test.

The outcomes of this study are compatible with Albino (2017) who attempted to assess how learners of English as a foreign language (EFL) improved their speaking fluency in a TBLT approach used with ninth-grade learners at PUNIV-Cazenga, a high school in Luanda. The findings indicated that learners improved in terms of their speaking fluency by maximizing their speed of speech production, increasing grammatical accuracy, elaborating on their utterances, and developing interactional language.

\section{Conclusion}

With reference to the results of the study, it can be concluded that Iranian EFL learners can benefit from task-based activities in speaking skill. Based on the findings of the present study, it can be concluded that the use of task-based activities in teaching and learning can produce positive results because they could improve students' speaking skill. The positive effects of using task-based activities became obvious after six sessions. Those students who were taught through task-based activities could speak more accurately and fluently after the treatment. Here, it can be claimed that receiving instruction through using task-based activities can facilitate English learning. The findings of the present study proved the benefits of incorporating task-based activities both in teaching and learning. As a result, it is recommended that teachers and students use taskbased activities for better teaching and learning.

\section{Implications of the Study}

This study has some implications for teachers and students. Through tasks, teachers can encourage cooperative learning among the students. The results of the study are beneficial for the students. Doing task-based activities can help the students to be involved in learning process. Students tend to be active and participate with great motivation towards tasks and activities in a class environment. Tasks offer a platform for students to display their skills through their efforts and develops them further. Language learners work and co-operate with each other in groups which builds bonds between them. When working in groups they are able to display and produce meaningful interaction on a given topic. Also, the class work together and assess the whole outcome of the lesson. Material developers can incorporate task-based activities and exercises in the English textbooks.

\section{Limitations and Suggestions of the Study}

Like any other study, this study also has a number of limitations, some of which could influence the findings and restrict the generalizability of the results. Firstly, in the present study, the number of the 
participants were limited to 50 students. However, working with bigger groups is more difficult and timeconsuming. Secondly, only one level (intermediate) of English students were participated in this study. Thirdly, only female students were included in this study, therefore; the results may not be generalizable to the male students. Fourthly, only 14 to 17 years old students were included in this study.

Next studies are needed to verify the current study results and to continue exploring the impacts of task-based activities on other skills and sub-skills. The future research should also extend the amount of time to determine maintenance of treatment effects. Future studies are suggested to include both female and male students as the participants. Upcoming studies are offered to determine if the treatment is equally useful in diverse populations and other geographical areas. Next studies can include more participants to get richer results. Future research should look at different ages and a wider variety of environments, to see how far the benefits of taskbased activities extend.

\section{References}

Albino, G. (2017). Improving speaking fluency in a task-based language teaching approach: The case of EFL learners at PUNIV-Cazenga. SAGE Open April-June, 4(6), $1-11$

Brown, G., \& Yule, G. (1983). Teaching the spoken language. Cambridge: Cambridge University Press.

Burkart, J. S. (1998). Spoken language: what it is and how to teach it. In modules for the professional preparation of teaching assistants in foreign languages. Washington, DC: center for applied linguistics.

Florez, M. A. C. (1999). Improving adult English language learners' speaking skill. National center for ESL literacy education. Washington: applied linguistics center.

Gunawan, M. (2016). The effect of task-based language teaching approach in developing speaking skill of the eighth-grade students of SMP Negeri 6 Watampone and their attitude toward English. Journal Perspektif ISSN, 1, 104-109.

Harmer, J. (2000). How to teach English. Foreign Language Teaching and Research Press.

Hashemifardnia, A., Rasooyar, H., \& Sepehri, M. (2019). Enhancing Iranian EFL Learners` Speaking Fluency through Using Task-based Activities. Global Journal of Foreign Language Teaching, 9 (1), 24-32.

Housen, A., Kuiken, F., \& Vedder, I. (2012). Complexity, accuracy and fluency. In A. Housen, F. Kuiken., \& I. Vedder (Eds.). Dimensions of L2 performance and proficiency: Complexity, accuracy and fluency in SLA (pp. 1 -20). Amsterdam: John Benjamins.

Hughes, A. (2003). Testing for language teachers (2nd ed.). Cambridge: Cambridge University Press.

Larsen-Freeman, D. (2000). Techniques and principles in language teaching. Oxford University.

Long, M. (2009). Methodological principles for language teaching. In M. Long \& C. Doughty (Eds.), Handbook of language teaching (pp. 373-94). Chichester, England: Wiley-Blackwell.

Mackey, A. (2008). Conversational interaction in second language acquisition: A collection of empirical studies. Oxford, England: Oxford University Press.

Mackey, A., \& Polio, C. (2009). Multiple perspectives on interaction in second language acquisition. London, England: Routledge.

Namaziandost, E. (2017). The effect of taskbased language teaching on motivation and grammatical achievement of EFL junior high school students. Advances in Language and Literary Studies, 8(2), 244-259.

Namaziandost, E., \& Çakmak, F. (2020). An account of EFL learners' self-efficacy and gender in the Flipped Classroom Model. Education and Information 
Technologies, 25(2), 4041-4055. https://doi. org/10.1007/s10639-020-10167-7.

Namaziandost, E., Razmi, M. H., Hernández, R. M., Ocaña-Fernández, Y., \& Khabir, M. (2021a). Synchronous CMC text chat versus synchronous CMC voice chat: impacts on EFL learners' oral proficiency and anxiety. Journal of Research on Technology in Education. In press. DOI: $\underline{10.1080 / 15391523.2021 .1906362}$

Namaziandost, E., Razmi, M. H., Tilwani, S. A., \& Pourhosein Gilakjani, A. (2021b). The impact of authentic materials on reading comprehension, motivation, and anxiety among Iranian male EFL learners. Reading \& Writing Quarterly. In press. DOI: $10.1080 / 10573569.2021 .1892001$.

Namaziandost, E., Sawalmeh, M. H. M., \& Izadpanah Soltanabadi, M. (2020). The effects of spaced versus massed distribution instruction on EFL learners' vocabulary recall and retention. Cogent Education, 7(1). DOI: 10.1080/2331186X.2020.1792261

Namaziandost, E., Shafiee, S., \& Ziafar, M. (2020). Investigating the impact of genre-based teaching (GBT) on intermediate EFL learners' listening improvement. Research in English Language Pedagogy, 8(2), 263-283.

Nazara, S. (2011). Students' Perception on English Foreign Language Speaking Skill Development. Jakarta: Universitas Kristen Indonesia.
Noshad, A., \& Zamanian, M. (2017). The effect of taskbased activities on Iranian beginner EFL learners' listening comprehension. Journal of Studies in Learning and Teaching English, 6(11), 1-22.

Nunan, D. (2004). Task-based language teaching. Cambridge: Cambridge University Press.

Richards, J., \& Schmidt, R. (2002). Dictionary of language teaching and applied linguistics. London: Pearson Education.

Robinson, P. (2011). Task-Based language learning. Ann Arbor, MI: Language Learning Research Club, University of Michigan.

Shakibaei, G., Shahamat, F., \& Namaziandost, E. (2019). The effect of using authentic texts on Iranian EFL learners' incidental vocabulary learning: The case of English newspaper. International Journal of Linguistics, Literature and Translation (IJLLT), 2(5), 422-432

Skehan, P. (2014). Investigating a processing perspective on task performance. Amsterdam, Netherlands: John Benjamins.

Skehan, P., \& Foster, P. (1999). The influence of source of planning and focus of planning on task-based performance. Language teaching Research, 3 (3), 215247.

Thornbury, S. (2000). Accuracy, fluency and complexity. English teaching professional, 1(6), 3-6. 